\title{
Sphingobacterium antarcticus sp. nov., a Psychrotrophic Bacterium from the Soils of Schirmacher Oasis, Antarctica
}

\author{
SISINTHY SHIVAJI,* M. K. RAY, N. SHYAMALA RAO, L. SAISREE, M. V. JAGANNADHAM, \\ G. SESHU KUMAR, G. S. N. REDDY, AND PUSHPA M. BHARGAVA \\ Centre for Cellular \& Molecular Biology, Uppal Road, Hyderabad 500 007, India
}

\begin{abstract}
Two pure cultures of bacteria isolated from soil samples collected in Schirmacher Oasis, Antarctica, conformed to the definition of the genus Sphingobacterium. They differed from all of the known species of Sphingobacterium in being psychrotrophic. The G+C contents of the DNA of the two strains were found to be 39.3 and $40.3 \mathrm{~mol} \%$, and DNA-DNA hybridization studies indicated $7 \%$ homology with $S$. multivorum and $S$. spiritivorum. The name Sphingobacterium antarcticus sp. nov. is proposed for the two Antarctic strains. The type strain is 4BY (MTCC 675), and it has been deposited with the Microbial Type Culture Collection, Institute of Microbial Technology, Chandigarh, India.
\end{abstract}

Until 1984, the genus Flavobacterium was extremely heterogeneous and included species which were gram negative, formed yellow or orange colonies, produced acid from carbohydrates, were either motile by peritrichous flagella or nonmotile, and which had either high (63 to $70 \mathrm{~mol} \%$ ) or low ( 26 to $34 \mathrm{~mol} \%$ ) $\mathrm{G}+\mathrm{C}$ contents of their DNA (38). The genus was eventually restricted to only those gram-negative, nonmotile, yellow, rod-shaped bacteria that had a low $\mathrm{G}+\mathrm{C}$ content $(30$ to $42 \%)(10,25,35)$. On the basis of these criteria, seven distinct species, namely $F$. aquatile, $F$. breve, $F$. balustinum, $F$. meningosepticum, $F$. odoratum, $F$. multivorum, and $F$. spiritivorum $(9-11,25,39)$, were found to conform to the genus. Since then, at least three more new species of Flavobacterium, viz. F. indologenes, $F$. yabuuchiae, and $F$. mizutaii, have been identified $(12,41)$. A detailed study based on the phenotypic characteristics, cellular lipid composition, and G+C contents of DNA of 41 strains of Flavobacterium belonging to five different species (namely $F$. spiritivorum, $F$. multivorum, $F$. meningosepticum, $F$. odoratum, and $F$. breve) led to the formation of a new genus, Sphingobacterium (41). This genus was distinguished from the genus Flavobacterium by the presence of high concentrations of sphingophospholipids in its strains. On the basis of this criterion, $F$. multivorum and $F$. spiritivorum have been renamed Sphingobacterium multivorum and $S$. spiritivorum (41).

Our earlier studies on the terrestrial microorganisms of Schirmacher Oasis, Antarctica, indicated the presence of a heterogeneous population of bacteria and yeast $(21,26-29)$. The ten gram-negative, motile, rod-shaped bacteria were identified as Pseudomonas fluorescens, Pseudomonas putida, and Pseudomonas syringae (29), the thirteen grampositive, nonmotile rods were identified as Arthrobacter globiformis, Arthrobacter pascens, and Arthrobacter protophorimiae (27), and the five gram-positive coccoid bacteria were identified as Micrococcus roseus and Planococcus spp. (28).

The present study describes two isolates of bacteria from the soils of Antarctica. Both isolates had all of the characteristics of Sphingobacterium but did not conform to any of the known species. We therefore propose that they be recognized as a new species, with the name $S$. antarcticus.

\footnotetext{
* Corresponding author
}

To our knowledge, the present report is the first to describe Sphingobacterium spp. isolated from Antarctica.

\section{MATERIALS AND METHODS}

Source of the organisms, media, and growth conditions. Soil samples were collected around Lake Zub, Schirmacher Oasis $\left(75^{\circ} 45^{\prime} 12^{\prime \prime} \mathrm{S}, 11^{\circ} 46^{\prime} \mathrm{E}\right)$, Antarctica, during the third week of January, 1985. The soil temperature varied from $+6^{\circ} \mathrm{C}$ to $-6^{\circ} \mathrm{C}$. These samples were appropriately diluted, plated on the surface of medium plates containing $0.5 \%$ peptone, $0.1 \%$ yeast extract, and $1.5 \%$ agar $(\mathrm{pH} \mathrm{6.9)}$, and incubated at $10^{\circ} \mathrm{C}$. Details of the study site, sampling area, and mode of collection of the samples have been described earlier $(21,27-29)$. Fewer than $1 \%$ of the bacterial colonies that appeared after 1 to 2 weeks were yellow. These yellow colonies could be divided into two main types on the basis of colony size, shape, and intensity of color. Pure cultures of these two types of yellow bacteria-the pale yellow and the bright yellow colonies-isolated from two different soil sites close to one another were established and designated 4BY and $6 \mathrm{BY}$, respectively. The optimum temperature, $\mathrm{pH}$, and salt concentration for the growth of $4 \mathrm{BY}$ and $6 \mathrm{BY}$ were determined by using the medium described above.

Morphology, motility, and biochemical tests. Cultures in the logarithmic phase of growth were observed under the phase-contrast microscope to determine their shape and size. Motility was determined by direct observation of an overnight culture by using the hanging drop method and by the piercing of a soft-agar medium. The ability of the bacteria to glide was determined as described earlier by Holmes et al. (10). Staining of the flagella was done by the method of silver impregnation (1) by using Pseudomonas aeruginosa as a positive control.

The activities of catalase, oxidase, phosphatase, gelatinase, urease, arginine dihydrolyase, lysine decarboxylase, acylamidase, and $\beta$-galactosidase $(8,41)$; the production of indole; growth on MacConkey agar, cetrimide agar, citrate agar, or $\beta$-hydroxybutyrate; reduction of nitrate and nitrite; levan formation from sucrose; hydrolysis of starch, esculin, Tween 20 , and Tween $80(8,32,33)$; production of hydrogen sulfide; pigment production on King's A and B medium (14); production of acid and/or gas from different carbon compounds (13); and accumulation of poly- $\beta$-hydroxybutyrate (19) were monitored according to the references cited

The sensitivity to antibiotics, the isolation of DNA, and 
the $\mathrm{G}+\mathrm{C}$ content of the DNA of the cultures was determined by standard methods $(15,24,28,29)$. DNA-DNA hybridization was performed by the membrane filter method (37). DNA was denatured by boiling in $0.2 \mathrm{M} \mathrm{NaOH}$ for 5 min and then quickly chilled on ice and neutralized with $\mathrm{HCl}$. Denatured DNA was dotted onto nitrocellulose and immobilized by baking at $80^{\circ} \mathrm{C}$ for $2 \mathrm{~h}$. The filters with the fixed DNA were prehybridized in a buffer containing $4 \times$ SSC $(1 \times$ SSC is $0.15 \mathrm{M} \mathrm{NaCl}$ plus $0.015 \mathrm{M}$ sodium citrate), $5 \times$ Denhardt medium (4), calf thymus DNA $(100 \mu \mathrm{g} / \mathrm{ml})$, and $1 \%$ sodium dodecyl sulfate for $2 \mathrm{~h}$ at $65^{\circ} \mathrm{C}$ and then hybridized in the same buffer under similar conditions but in the presence of labelled DNA. DNA was labelled by nick translation (23).

Identification of fatty acids. Lyophilized $4 \mathrm{BY}$ and $6 \mathrm{BY}$ cells $(100 \mathrm{mg})$ were hydrolyzed with methanolic $\mathrm{KOH}$ and converted to methyl esters in $0.2 \%$ sulfuric acid for $2 \mathrm{~h}$ at $70^{\circ} \mathrm{C}$ in a water bath. The resulting fatty acid methyl esters were extracted with chloroform and chromatographed on a Finnigan Mat 1020 automated gas chromatograph-mass spectrometer by using an SE30, 25-m capillary column in the temperature range of 120 to $200^{\circ} \mathrm{C}$. The increase in temperature was $8^{\circ} \mathrm{C} / \mathrm{min}$. Fatty acids were identified on the basis of mass spectral data (36).

Identification of sphingolipids. Lipids were extracted from a lyophilized cell pellet (20) and used for the isolation of sphingolipids (5). Sphingolipids were resolved by thin-layer chromatography and detected by spraying with ninhydrin and/or Clorox-benzidine as described by Skispski and Barclay (31). Long-chain bases were prepared from the sphingolipids (42) and visualized with ninhydrin reagent. Infrared spectra of the long-chain bases were recorded in chloroform on a Perkin Elmer infrared spectrophotometer, and the mass spectra were recorded at $20 \mathrm{eV}$ at a probe temperature of $210^{\circ} \mathrm{C}$ on a VG Micromass $7070-\mathrm{H}$ mass spectrometer.

Reference strains. Sphingobacterium multivorum (earlier known as $F$. multivorum NCTC $11343^{\mathrm{T}}$ and NCTC $11033^{\mathrm{T}}$ ) and $S$. spiritivorum (earlier known as $F$. spiritivorum NCTC $11386^{\mathrm{T}}$ and NCTC $11387^{\mathrm{T}}$ ) were used as positive controls in studies related to morphology, motility, biochemical tests, and identification of fatty acids and sphingolipids.

Bacterial pigment. Lyophilized $4 \mathrm{BY}$ and $6 \mathrm{BY}$ cells $(\sim 20$ $\mathrm{mg}$ ) were suspended in methanol and extracted by vigorous vortexing for $30 \mathrm{~min}$. The methanol extract was centrifuged, the yellow clear supernatant was recovered, and the absorption spectrum was recorded in an Hitachi 330 spectrometer.

\section{RESULTS AND DISCUSSION}

Colonies of 4BY and 6BY were isolated and purified from two different soil samples (collected around Lake Zub), which yielded about $1 \times 10^{3}$ colonies per $\mathrm{g}$ of soil. The colonies of $4 \mathrm{BY}$ and $6 \mathrm{BY}$ were yellow, translucent, round, smooth, and slightly convex. The two types of colonies differed in that $4 \mathrm{BY}$ was pale yellow in color and 1 to $2 \mathrm{~mm}$ in diameter, whereas 6BY was bright yellow and more than $2 \mathrm{~mm}$ in diameter. The yellow pigment could be extracted from both 4BY and 6BY with methanol. The absorption spectrum of the pigment indicated the presence of three absorption maxima in each case, but the positions of the absorption maxima varied. In $4 \mathrm{BY}$ the yellow pigment showed peaks at 396,442 , and $464 \mathrm{~nm}$, whereas in $6 \mathrm{BY}$ the peaks were at 420,447 , and $472 \mathrm{~nm}$. Cells from these colonies were gram-negative, nonsporeforming, straight rods, nonmotile in soft agar and in hanging drop preparations, and they did not possess any flagella. The cells also did not exhibit any gliding motility. Under optimum growth conditions $\left(25^{\circ} \mathrm{C}\right.$ and
$\mathrm{pH} 6.9$ ), the generation time of $4 \mathrm{BY}$ and $6 \mathrm{BY}$ was $2.5 \mathrm{~h}$; at $30^{\circ} \mathrm{C}$ and $\mathrm{pH} 6.9$ it was $6 \mathrm{~h}$. At $5^{\circ} \mathrm{C}$ it was $20 \mathrm{~h}$.

The two isolates had the following characteristics in common. They were nonfermentative; were catalase, oxidase, urease, gelatinase, $\beta$-galactosidase, and phosphatase positive; did not accumulate poly- $\beta$-hydroxybutyrate; hydrolyzed Tween 20 , Tween 80 , esculin, and gelatin but not starch; did not reduce nitrate or nitrite; did not produce indole; produced hydrogen sulfide; and were capable of growth on $\beta$-hydroxybutyrate and MacConkey agar but not on cetrimide agar. Citrate, acetate, and malonate were not utilized; casein was not digested; arginine dihydrolase and lysine decarboxylase were not produced. Both isolates produced acid from glucose $(1 \%$ and $10 \%)$, lactose $(1 \%$ and $10 \%)$, cellulose, raffinose, and mannose; acid was not produced from fructose, sucrose, galactose, maltose, arabinose, melezitose, rhamnose, sorbitol, glycerol, mesoinositol, xylose, salicin, ethanol, and mannitol. The isolates did not accumulate poly- $\beta$-hydroxybutyrate, produced yellow nondiffusible pigments, and did not produce fluorescent pigment on King's A and B medium.

$4 \mathrm{BY}$ and $6 \mathrm{BY}$ had very similar nutritional requirements. They could grow on Minimal A medium supplemented with a carbon source such as L-arabinose, D-xylose, L-rhamnose, D-ribose, glucose, D-fructose, D-mannose, D-galactose, sucrose, maltose, lactose, raffinose, mannitol, glycerol, $m$-inositol, sorbitol, succinate, pyruvate, lactate, glutamate, formate, $\beta$-hydroxybutyrate, and malate. Starch, cellulose, melibiose, glycogen, dextrin, and inulin were not utilized as a carbon source.

The main cellular fatty acid components of $4 \mathrm{BY}$ and $6 \mathrm{BY}$ were identified as $C_{14: 0}, C_{16: 0}, C_{16: 1}, C_{17: 1}$, and $\mathrm{iC}_{15: 0}$. Of these, $\mathrm{iC}_{15: 0}$ and $\mathrm{C}_{16: 1}$ were the most predominant, constituting 29 and $56 \%$ of the total cellular fatty acid content, respectively. By using the solvent system chloroform-methanol-acetic acid-water $(100: 20: 12: 5)$, it was possible to resolve the sphingolipids of $4 \mathrm{BY}$ and $6 \mathrm{BY}$ into two major spots (with $R_{f}$ s of 0.26 and 0.32 , respectively) and two minor spots (with $R_{f}$ s of 0.41 and 0.51 , respectively). In $S$. multivorum, sphingolipids with $R_{f} s$ of $0.32,0.41$, and 0.51 were present but the sphingolipid with an $R_{f}$ of 0.26 was not detected. In $4 \mathrm{BY}$ and $6 \mathrm{BY}$, sphingophospholipids constituted $23 \%$ of the total phospholipid. This is in close agreement with the $21 \%$ reported for $S$. multivorum (41). The long-chain bases obtained from the sphingolipids of $4 \mathrm{BY}, 6 \mathrm{BY}$, and $S$. multivorum (NCTC $11343^{\mathrm{T}}$ ) resolved into three spots on silica gel thin-layer chromatography plates $(0.5 \mathrm{~mm}$ thick) by using the solvent system chloroform-methanol-water $(65: 25: 4, \mathrm{vol} / \mathrm{vol} /$ vol). Long-chain bases with $R_{f}$ s of 0.32 and 0.57 were detected in $4 \mathrm{BY}, 6 \mathrm{BY}$, and $S$. multivorum, but the third long-chain base had an $R_{f}$ of 0.09 in $6 \mathrm{BY}$ and $4 \mathrm{BY}$ and 0.18 in $S$. multivorum. The presence of an amino group in the long-chain bases was confirmed by a positive ninhydrin reaction and a broad band at $3,280 \mathrm{~cm}^{-1}$ in the infrared spectrum. The $\mathrm{OH}$ group was not clearly detected, probably because of an overlap of the amino and $\mathrm{OH}$ group bands. Preliminary mass spectral studies of the three long-chain bases obtained by scraping preparative thin-layer chromatography plates were conducted, and the results based on the molecular ion peaks

$$
\left(\mathrm{M}^{+}\right), \mathrm{M}^{+}-\mathrm{H}_{2} \mathrm{O} \text {, and } \mathrm{M}^{+}-\left(\mathrm{HO}-\mathrm{CH}_{2}-\mathrm{CH}\right)
$$

indicate the presence of long-chain bases corresponding to $\mathrm{C}_{16: 0}, \mathrm{C}_{17: 0}$, and $\mathrm{C}_{18: 1}$ with a molecular mass of 273,287 , and 
TABLE 1. Characteristics in which the two strains of $S$. antarcticus differed from each other or from $S$. multivorum

\begin{tabular}{|c|c|c|c|}
\hline \multirow[b]{2}{*}{ Characteristic } & \multicolumn{3}{|c|}{ Result for: } \\
\hline & 4BY & $6 \mathrm{BY}$ & $\begin{array}{c}\text { S. multivorum } \\
\text { (NCTC } 11343^{\mathrm{T}} \text { ) }\end{array}$ \\
\hline Colony size (diam) & $1-2 \mathrm{~mm}$ & $>2 \mathrm{~mm}$ & $1 \mathrm{~mm}$ \\
\hline Colony color & Pale yellow & Bright yellow & Yellow \\
\hline Growth at $37^{\circ} \mathrm{C}$ & - & - & + \\
\hline Growth at $2^{\circ} \mathrm{C}$ & + & + & - \\
\hline \multicolumn{4}{|c|}{ Acid production from: } \\
\hline Melezitose & - & - & + \\
\hline Fructose & - & - & + \\
\hline Sucrose & - & - & + \\
\hline Arabinose & - & - & + \\
\hline Glycerol & - & - & + \\
\hline Xylose & - & - & + \\
\hline Galactose & - & - & + \\
\hline Salicin & - & - & + \\
\hline Maltose & - & - & + \\
\hline Gelatinase & + & + & - \\
\hline Major fatty acid & $\mathrm{C}_{16: 1}$ & $\mathrm{C}_{16: 1}$ & $\mathrm{i}-2-\mathrm{OH}-\mathrm{C}_{15: 0}$ \\
\hline $\mathrm{Mol} \% \mathrm{G}+\mathrm{C}$ & $39.3 \pm 1$ & $40.3 \pm 1$ & 40.5 \\
\hline
\end{tabular}

299, respectively. The $\mathrm{G}+\mathrm{C}$ contents of the DNA of 4BY and 6BY were 39.3 and $40.3 \mathrm{~mol} \%$, respectively. DNA-DNA hybridization studies indicated $100 \%$ homology between $4 B Y$ and $6 B Y$. On the basis of the characteristics described above, 4BY and $6 \mathrm{BY}$ were identified as belonging to the genus Sphingobacterium $(12,41)$. Earlier studies had indicated the presence of the closely related genus Flavobacterium in the soils and the marine environment of Antarctica $(2,3)$.

Members of the genus Sphingobacterium differ from Flavobacterium spp. in that they contain sphingolipids, do not produce indole, do not grow on skim milk acetate agar, and are gelatinase negative (41); they can be distinguished from Cytophaga and Flexibacter spp. in that they have a carotenoidlike pigment and do not exhibit gliding motility.

So far, three species of mesophilic Sphingobacterium, namely $S$. spiritivorum, $S$. multivorum, and $S$. mizutaii, have been recognized $(12,41)$. These three species could be distinguished from one another on the basis of their ability to produce acid aerobically from ethanol, mannitol, and rhamnose and on their ability to hydrolyze starch (41). Since 4BY and 6BY give a negative reaction for all of the tests described above, they closely resemble $S$. multivorum, not $S$. spiritivorum (which is positive for all of the tests) or $S$. mizutaii (which could produce acid from rhamnose but is negative with respect to the other three tests). Furthermore, 4BY and $6 \mathrm{BY}$ had $\mathrm{G}+\mathrm{C}$ contents of 39.3 and $40.3 \mathrm{~mol} \%$, respectively, and produced acid aerobically only from glucose, raffinose, cellobiose, lactose, and mannose, thus closely resembling $S$. multivorum.

Some of the characteristics in which the present isolates differed from $S$. multivorum are listed in Table 1. Apart from these characteristics, distinct differences are observed in the fatty acid compositions. In the type strain of $F$. multivorum, the predominant cellular fatty acids were the branched and hydroxy fatty acids, with i-2-OH- $\mathrm{C}_{15: 0}, \mathrm{i}-3-\mathrm{OH}-\mathrm{C}_{17: 0}$, and $\mathrm{i}-\mathrm{C}_{15: 0}$ constituting 35,10 , and $27 \%$, respectively (41), and $\mathrm{C}_{16.1}$, which constituted $13 \%$. But in $4 \mathrm{BY}$ and $6 \mathrm{BY}$ the predominant fatty acids were $\mathrm{i}-\mathrm{C}_{15: 0}(29 \%)$ and $\mathrm{C}_{16: 1}(56 \%)$ and contained only trace amounts of hydroxy fatty acids. Psychrotrophic bacteria are known to possess a greater
TABLE 2. Sensitivity of $S$. antarcticus from Schirmacher Oasis, Antarctica, to antibiotics ${ }^{a}$

\begin{tabular}{llllll}
\hline \multirow{2}{*}{ Antibiotic } & \multirow{2}{*}{ Concn } & \multicolumn{4}{c}{ Resistance (R) or sensitivity (S) of: } \\
\cline { 3 - 7 } & & S. multivorum & S. spiritivorum & 4BY & $6 \mathrm{BY}$ \\
\hline Streptomycin & $10 \mu \mathrm{g}$ & $\mathrm{R}$ & $\mathrm{R}$ & $\mathrm{R}$ & $\mathrm{R}$ \\
Ampicillin & $10 \mu \mathrm{g}$ & $\mathrm{R}$ & $\mathrm{R}$ & $\mathrm{R}$ & $\mathrm{R}$ \\
Gentamycin & $10 \mu \mathrm{g}$ & $\mathrm{R}$ & $\mathrm{R}$ & $\mathrm{R}$ & $\mathrm{R}$ \\
Kanamycin & $40 \mu \mathrm{g}$ & $\mathrm{R}$ & $\mathrm{R}$ & $\mathrm{R}$ & $\mathrm{R}$ \\
Polymyxin B & $300 \mathrm{units}$ & $\mathrm{R}$ & $\mathrm{ND}$ & $\mathrm{R}$ & $\mathrm{R}$ \\
Tobramycin & $15 \mu \mathrm{g}$ & $\mathrm{R}$ & $\mathrm{ND}$ & $\mathrm{R}$ & $\mathrm{R}$ \\
Erythromycin & $15 \mu \mathrm{g}$ & $\mathrm{R}$ & $\mathrm{R}$ & $\mathrm{R}$ & $\mathrm{R}$ \\
Penicillin & $10 \mathrm{units}$ & $\mathrm{ND}$ & $\mathrm{ND}$ & $\mathrm{R}$ & $\mathrm{R}$ \\
Carbenicillin & $50 \mu \mathrm{g}$ & $\mathrm{R}$ & $\mathrm{R}$ & $\mathrm{R}$ & $\mathrm{R}$ \\
Nystatin & $100 \mu \mathrm{g}$ & $\mathrm{ND}$ & $\mathrm{ND}$ & $\mathrm{R}$ & $\mathrm{R}$ \\
Rifamycin & $10 \mu \mathrm{g}$ & $\mathrm{S}$ & $\mathrm{S}$ & $\mathrm{S}$ & $\mathrm{S}$ \\
Tetracycline & $30 \mu \mathrm{g}$ & $\mathrm{R}$ & $\mathrm{S}$ & $\mathrm{S}$ & $\mathrm{S}$ \\
Nalidixic acid & $30 \mu \mathrm{g}$ & $\mathrm{S}$ & $\mathrm{ND}$ & $\mathrm{S}$ & $\mathrm{S}$ \\
Novobiocin & $10 \mu \mathrm{g}$ & $\mathrm{ND}$ & $\mathrm{ND}$ & $\mathrm{S}$ & $\mathrm{S}$ \\
Bacitracin & $10 \mathrm{units}$ & $\mathrm{ND}$ & $\mathrm{ND}$ & $\mathrm{S}$ & $\mathrm{R}$ \\
Vancomycin & $30 \mu \mathrm{g}$ & $\mathrm{ND}$ & $\mathrm{ND}$ & $\mathrm{S}$ & $\mathrm{R}$ \\
Chloramphenicol & $30 \mu \mathrm{g}$ & $\mathrm{S}$ & $\mathrm{ND}$ & $\mathrm{R}$ & $\mathrm{S}$ \\
Colistin & $10 \mu \mathrm{g}$ & $\mathrm{ND}$ & $\mathrm{ND}$ & $\mathrm{R}$ & $\mathrm{S}$ \\
Trimethoprim & $10 \mu \mathrm{g}$ & $\mathrm{S}$ & $\mathrm{ND}$ & $\mathrm{S}$ & $\mathrm{R}$ \\
\hline
\end{tabular}

a The concentration refers to the quantity of antibiotic per disc.

${ }^{b} \mathrm{ND}$, not done.

proportion of unsaturated fatty acids so as to increase the membrane fluidity at low temperatures $(7,18)$. This may be the reason for the high proportion of $\mathrm{C}_{16: 1}(56 \%)$ in $4 \mathrm{BY}$ and $6 \mathrm{BY}$ as compared to $S$. multivorum (13\%). However, it is difficult to give reasons as to why hydroxy fatty acids are present in only minimal amounts in 4BY and 6BY. A detailed study of the cellular fatty acid composition of nine isolates of Sphingobacterium belonging to three different species also indicated some prominent differences. For instance, in two isolates of $S$. multivorum, NCTC $11343^{\mathrm{T}}$ and GIFU 926, fatty acids $\mathrm{C}_{16: 1}$, i- $\mathrm{C}_{15: 0}$, i-2-OH- $\mathrm{C}_{15: 0}$, and $\mathrm{i}-3-\mathrm{OH}-\mathrm{C}_{17: 0}$ constituted 13 and $29 \%, 27$ and $18 \%, 35$ and $19 \%$, and 10 and $1 \%$, respectively (41). Furthermore, NCTC $11343^{\mathrm{T}}$ did not possess the fatty acids $\mathrm{C}_{14: 0}, 2-\mathrm{OH}-\mathrm{C}_{14: 0}$, and 3-OH- $\mathrm{C}_{16: 0}$, and GIFU 926 did not possess $\mathrm{i}-\mathrm{C}_{17: 1}$. DNA-DNA homology studies indicated $100 \%$ homology between $4 \mathrm{BY}$ and $6 \mathrm{BY}$ but both showed only about $10 \%$ hybridization with $S$. multivorum and about $5 \%$ with $S$. spiritivorum, respectively. The sensitivity of the isolates to antibiotics was also slightly different from that of $S$. multivorum (Table 2). The present isolates of $S$. antarcticus also differ from $F$. yabuuchiae (which shows about $64 \%$ homology with $S$. spiritivorum) and $F$. thalpophilum (which is capable of growth at $42^{\circ} \mathrm{C}$ and produces acid from arabinose, rhamnose, glycerol, and mannitol and reduces nitrate) (12). Since the two isolates of Flavobacterium described above possess characteristics of the genus Sphingobacterium, it was suggested that the isolates be transferred to the genus Sphingobacterium (12) provided that taxonomists are convinced. We are of the opinion that isolates which differ in their fatty acid compositions due to their psychrotrophic or thermophilic nature compared with the type strains of Sphingobacterium should be included in Sphingobacterium.

Earlier studies had also indicated that a number of bacterial isolates from Antarctica possess unusual characteristics and thus cannot be readily identified as existing species (17, $22,27-30,34,40$ ). When the differences between the Antarctic isolates and the known species have been many and distinct, the former have been assigned to new species such 
as Halomonas subglaciescola (6) and Flectobacillus glomeratus (16). Taking all the characteristics described for 4BY and $6 \mathrm{BY}$ into account, it seems appropriate to assign them to a new species of Sphingobacterium for which the name $S$. antarcticus is proposed. The present study is the first report on the taxonomy of Sphingobacterium isolates from the soils of continental Antarctica.

Description of Sphingobacterium antarcticus sp. nov. Sphingobacterium antarcticus (ănt.ärk'ti.kŭs. N.L. antarcticus, pertaining to the antarctic) cells are aerobic gramnegative rods, length 2 to $3 \mu \mathrm{m}$, width 0.5 to $1 \mu \mathrm{m}$. Nonmotile. Colony morphology on peptone-yeast extract agar: round, yellow, smooth, slightly convex, 1 to $2 \mathrm{~mm}$ in diameter. No growth factors required. Optimal growth temperature, $25^{\circ} \mathrm{C}$; can grow between 2 and $30^{\circ} \mathrm{C}$, but not at temperatures above $30^{\circ} \mathrm{C}$. Grow between $\mathrm{pH} 6$ and 8 , with optimum growth at $\mathrm{pH} 6.9 . \mathrm{NaCl}$ not required for growth; can tolerate up to $0.5 \mathrm{M} \mathrm{NaCl}$.

Utilizes a wide variety of carbon sources and can acidify glucose, lactose, cellobiose, raffinose, and mannose. Does not produce gas from carbohydrates.

Catalase, oxidase, phosphatase, gelatinase, urease, and $\beta$-galactosidase positive. Tween 20 , Tween 80 , and esculin are hydrolyzed. Starch is not hydrolyzed. The major fatty acid is $\mathrm{C}_{16: 1}$; the long-chain bases of the sphingophospholipid are $C_{16: 1}, C_{17: 0}$, and $C_{16: 0}$. DNA base composition is 39.3 to 40.3 mol\% $\mathrm{G}+\mathrm{C}$. Habitat is soil from Schirmacher Oasis, Antarctica. The type strain is 4BY (= MTCC 675).

\section{ACKNOWLEDGMENTS}

We are grateful to Vipula Sheth for the technical assistance provided during the initial stages of this work. Our thanks also are due to the Director, Indian Institute of Chemical Technology, Hyderabad, for providing us with facilities for mass spectra and to V. J. Rao for useful suggestions.

\section{REFERENCES}

1. Blenden, D. C., and M. S. Goldberg. 1965. Silver impregnation stain for Leptospira and flagella. J. Bacteriol. 89:899-900.

2. Boyd, W. L., and I. Rothenberg. 1968. Ecology of soil microorganisms in the vicinity of Almirante Brown Base. Antarct. J. USA 3:60-63.

3. Darling, C. A., and P. A. Siple. 1941. Bacteria of Antarctica. J. Bacteriol. 42:83-98.

4. Denhardt, D. T. 1966. A membrane filter technique for the detection of complementary DNA. Biochem. Biophys. Res. Commun. 23:641-646.

5. Dittermer, D. C., and M. A. Wells. 1969. Quantitative and qualitative analysis of lipids and lipid components. Methods Enzymol. 14:482-580.

6. Franzmann, P. D., H. R. Burton, and T. A. McMeekin. 1987. Halomonas subglaciescola, a new species of halotolerant bacteria isolated from Antarctica. Int. J. Syst. Bacteriol. 37:27-34.

7. Gounot, A. M. 1986. Psychrophilic and psychrotrophic microorganisms. Experientia 42:1192-1197.

8. Holding, A. J., and J. G. Collee. 1971. Routine biochemical tests. Methods Microbiol. 6A:2-32.

9. Holmes, B., R. J. Owen, and D. G. Hollis. 1982. Flavobacterium spiritivorum, a new species isolated from human clinical specimens. Int. J. Syst. Bacteriol. 32:157-165.

10. Holmes, B., R. J. Owen, and T. A. McMeekin. 1984. Genus Flavobacterium, Bergey, Harrison, Breed, Hammer, and Huntoon 1923, $97^{\text {AL }}$, p. 353-361. In N. R. Krieg and J. G. Holt (ed.), Bergey's manual of systematic bacteriology, vol. 1 . Williams \& Wilkins, Baltimore.

11. Holmes, B., R. J. Owen, and R. E. Weaver. 1981. Flavobacterium multivorum, new species isolated from human clinical specimens and previously known as group IIK biotype 2 . Int. J. Syst. Bacteriol. 31:21-34.
12. Holmes, B., R. E. Weaver, A. G. Steigerwalt, and D. J. Brenner. 1988. A taxonomic study of Flavobacterium spiritivorum and Sphingobacterium mizutaii: proposal of Flavobacterium yabuuchiae sp. nov, and Flavobacterium mizutaii comb. nov. Int. J. Syst. Bacteriol. 38:348-353.

13. Hugh, R., and E. Leifson. 1953. The taxonomic significance of fermentative versus oxidative metabolism of carbohydrates by various gram-negative bacteria. J. Bacteriol. 66:24-26.

14. King, E. O., W. K. Ward, and D. E. Raney. 1954. Two simple media for the demonstration of pyocyanin and fluorescein. $\mathrm{J}$. Lab. Clin. Med. 44:301-307.

15. Marmur, J. 1961. Procedure for the isolation of deoxyribonucleic acid from microorganisms. J. Mol. Biol. 3:208-218.

16. McGuire, A. J., P. D. Franzmann, and T. A. McMeekin. 1987 Flectobacillus glomeratus sp. nov., a curved non-motile, pigmented bacterium isolated from Antarctic marine environments. Syst. Appl. Microbiol. 9:265-272.

17. Miller, K. J., and S. B. Leschine. 1984. A halotolerant Planococcus from Antarctic dry valley soil. Curr. Microbiol. 11:205210.

18. Morita, R. Y. 1975. Psychrophilic bacteria. Bacteriol. Rev. 39:146-167.

19. Ostle, A. G., and J. G. Holt. 1982. Nile blue A as a fluorescent stain for poly- $\beta$-hydroxybutyrate. Appl. Environ. Microbiol. 44:238-241.

20. Radin, N. S. 1969. Preparation of lipid extracts. Methods Enzymol. 14:245-254.

21. Ray, M. K., S. Shivaji, N. S. Rao, and P. M. Bhargava. 1989. Yeast strains from the Schirmacher Oasis, Antarctica. Polar Biol. 9:305-309.

22. Rees, G. N., P. H. Janssen, and C. G. Harfoot. 1986. An unusual strain of Desulfovibrio sp. from an Antarctic lake. FEMS Microbiol. Lett. 37:363-366.

23. Rigby, P. W. J., M. Dieckmann, C. Rhodes, and P. Berg. 1977. Labelling deoxyribonucleic acid to high specific activity in vitro by nick translation with DNA polymerase I. J. Mol. Biol. 113:237-245.

24. Schildkraut, C., and S. Leifson. 1965. Dependence of the melting temperature of DNA on salt concentration. Biopolymers 3:195208.

25. Shewan, J. M., and T. A. McMeekin. 1983. Taxonomy and ecology of Flavobacterium and related genera. Annu. Rev. Microbiol. 37:233-252.

26. Shivaji, S. 1987. A preliminary note on the bacteria and yeast of Antarctica. Department of Ocean Development, Government of India, Technical Publication. 4:155-157.

27. Shivaji, S., N. S. Rao, L. Saisree, G. S. N. Reddy, G. Seshu Kumar, and P. M. Bhargava. 1989. Isolates of Arthrobacter from the soils of Schirmacher Oasis, Antarctica. Polar Biol. 10:225-229.

28. Shivaji, S., N. S. Rao, L. Saisree, V. Sheth, G. S. N. Reddy, and P. M. Bhargava. 1988. Isolation and identification of Micrococcus roseus and Planococcus sp. from Schirmacher Oasis, Antarctica. J. Biosci. (Bangalore) 13:409-414.

29. Shivaji, S., N. S. Rao, L. Saisree, V. Sheth, G. S. N. Reddy, and P. M. Bhargava. 1989. Isolation and identification of Pseudomonas species from Schirmacher Oasis, Antarctica. Appl. Environ. Microbiol. 55:767-770.

30. Siebert, J., and P. Hirsch. 1988. Characterisation of 15 selected coccal bacteria isolated from Antarctic rock and soil samples from the McMurdo Valley (South Victoria Land). Polar Biol. 9:37-44.

31. Skispski, V. P., and M. Barclay. 1969. Thin layer chromatography of lipids. Methods Enzymol. 14:530-598.

32. Stainer, R. Y., N. J. Palleroni, and M. Doudroff. 1966. The aerobic Pseudomonas, a taxonomic study. J. Gen. Microbiol. 43:159-271.

33. Stolp, H., and D. Gadkari. 1981. Nonpathogenic members of the genus Pseudomonas, p. 719-741. In M. P. Starr, H. Stolp, and H. G. Schlegel (ed.), The prokaryotes, vol. 1. Springer Verlag, Berlin.

34. Tearle, P. V., and K. J. Richard. 1987. Ecophysiological grouping of environmental bacteria by API $20 \mathrm{NE}$ and fatty acid finger 
prints. J. Appl. Bacteriol. 63:497-503.

35. Thomson, K. S., and T. A. McMeekin. 1981. A comparison of some gram-negative, yellow pigmented rods isolated from environmental and clinical sources, p. 91-100. In $\mathrm{H}$. Reichenbach and O. B. Weeks (ed.), The Flavobacterium-Cytophaga group. Verlag Chemie, Weinheim, Germany.

36. Tornabene, T. G., E. Gelpi, and J. Oro. 1967. Identification of fatty acids and aliphatic hydrocarbons in Sarcina lutea by gas chromatography and combined gas chromatography-mass spectrometry. J. Bacteriol. 94:333-343.

37. Tourova, T. P., and A. S. Antonov. 1987. Identification of microorganisms by rapid DNA-DNA hybridisation. Methods Microbiol. 19:333-355.

38. Weeks, O. B. 1974. Genus Flavobacterium Bergey et al. 1923, 97, p. 357-364. In R. E. Buchanan and N. E. Gibbons (ed.), Bergey's manual of determinative bacteriology, 8th ed.
Williams \& Wilkins, Baltimore.

39. Weeks, O. B. 1981. The genus Flavobacterium, p. 1365-1370, In M. P. Starr, H. Stolp, H. G. Trüper, A. Balows, and H. G. Schlegel (ed.), The Prokaryotes, vol. 2. Springer Verlag, Berlin.

40. Wynn-Williams, D. D. 1983. Distribution and characterisation of Chromobacterium in the maritime and sub-Antarctic. Polar Biol. 2:101-108.

41. Yabuuchi, E., T. Kaneko, I. Yans, C. W. Moss, and N. Miyoshi. 1983. Sphingobacterium gen. nov., Sphingobacterium spiritivorum comb. nov., Sphingobacterium multivorum comb. nov., Sphingobacterium mitzutae sp. nov., and Flavobacterium indologenes sp. nov.: glucose-nonfermenting gram-negative rods in CDC Groups IIK-2 and IIb. Int. J. Syst. Bacteriol. 3:580-598.

42. Yano, I., I. Tomiyasu, and E. Yabuuchi. 1982. Long chain base composition of strains of three species of Sphingobacterium gen. nov. FEMS Microbiol. Lett. 15:303-308. 